\title{
WATER ABSORPTION IN BEAN SEEDS (Phaseolus vulgaris L.) DURING PROCESSING
}

\author{
LORENA BRITO MIRANDA * \\ PALLOMA RODRIGUES DE LIMA ** \\ GLÊNDARA APARECIDA DE SOUZA MARTINS *** \\ WARLEY GRAMACHO DA SILVA ****
}

\begin{abstract}
The purpose of this paper was to estimate and to evaluate the hydration curves of three kinds of dry bean varieties (Phaseolus vulgaris L.), besides adjusting the Peleg's model to the experimental values under several soaking temperatures. Bean seeds of pinto, black and red kidney varieties were soaked in distilled water in the temperatures of $20,30,40$ and $50^{\circ} \mathrm{C}$. The constant $\mathrm{C}_{1}$ (Peleg rate constant) significantly decreased with increase in temperature (20 a $50^{\circ} \mathrm{C}$ ) demonstrating that the initial rate of water absorption increased with temperature. The three bean varieties exhibited a high rate of water absorption in the beginning of the hydration process, being that Peleg's model adjusted satisfactorily to the experimental data.
\end{abstract}

KEY-WORDS: BEANS; SOAKING; WATER ABSORPTION; PELEG'S MODEL.

* Degree in Food Engineering, Universidade Federal do Tocantins (UFT), Palmas, TO, Brazil (e-mail: lorenabritom@hotmail.com).

** Degree in Food Engineering, UFT, Palmas, TO, Brazil (e-mail: pallomarodrigues@hotmail.com).

*** Teacher, Master's Degree in Food Science, UFT, Palmas (TO), Brazil (e-mail: glendarasouza@uft.edu.br).

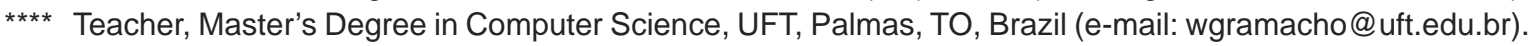




\section{INTRODUCTION}

Bean is one of the basic foods from several peoples, mainly Brazilians, constituting its major source of vegetable protein. Each $100 \mathrm{~g}$ of bean offers about 350 calories, $20-24 \mathrm{~g}$ of protein. It contains more fibers than cereals and is quantitatively a good source of iron (OLIVEIRA, 2005). But, since the decade of 1970 there was a vertiginous reduction on the bean consumption: almost $50 \%$. Being that some experts believe that changes in the menu is one of the reasons for the rise of obesity cases in Brazil, according to the research made by CONAB (2010).

In Brazil, consumer's preference for beans is regionalized and differentiated mainly about color and type of grain. In per capita terms, by mid of 2006, the product was mostly consumed in rural area (2.15 times more than in urban area) according to the FIEP (2006).

As stated by Chaves (2011), major classes of beans produced in Brazil are common color bean (predominantly represented by pinto group, but they can contain other groups as cranberry, canary and pink bean), common black and cowpea.

The common bean (Phaseolus vulgaris L.) is one of the mostly consumed leguminous in the world. Internal market absorbs production of common bean in Brazil and about $65 \%$ of its whole consumption is from the pinto commercial group (CHAVES, 2011).

Black bean is the most popular in Rio Grande do Sul, Santa Catarina, south and east of Paraná, Rio de Janeiro, southeast of Minas Gerais and south of Espírito Santo. In the rest of the country this kind of grain has little or almost no commercial value or acceptance. Beans of pinto grain type are accepted practically in whole Brazil (EMPRAPA, 2003). As stated by Costa (2007) consumption of the red kidney bean is restricted to determined regions, such as Zona da Mata Mineira.

Even after the consumption of beans reduction in the country, Brazil still has a considerable production of this leguminous. According to the SNA (2006), it is necessary that the country defines strategies and conduct studies to identify customers' preferences, as well as technological needs of industries so that it can supplied the market broadly and with quality. Thus, it is fundamental to invest in researches to support the bean culture development.

Transformation of leguminous like beans many times requires hydration of seeds as a first step to facilitate operations like canned foods. Therefore study of water absorption for these materials is important to food industries according to Maskan (2002).

Many studies evolving the water absorption kinetics in several agricultural products, as soy and wheat, have observed the influence of temperature in rate and amount of water distributed into the product (BOTELHO, 2009). Those studies enhance interest and importance of optimization and characterization of some grains immersion conditions and processing.

The mathematical modelling constitutes essential to simulate behavior of materials submitted to hydration process, may be used the models, theoretical and empirical (RESENDE \& CORRÊA, 2007). The first models studied, based on laws and theories, are more complex and evolve parameters that in most situations are not suitable for computational practices (MASKAN, 2002). On the other hand, empirical models, as indicated by Botelho et al. (2010), usually are more basic and of easy application, since are based on the experimental and dimensional data analysis as well as on the statistical analysis.

To describe the water absorption in grains and cereals a non-exponential empirical equation has been proposed. That model became known as Peleg's equation (MASKAN, 2002). Peleg (1988) proposed an empirical model and adjusted the data from literature of water absorption in milk powder and rice, obtaining correlation coefficients from the order of 0.95 to 0.99 . Due to its simplicity, in spite of not being derived from any physical law or diffusion theories, Peleg's model has been widely used to model the behavior of different grains and foods during hydration (COUTINHO, 2006).

The purpose of this study was to estimate and to evaluate the hydration curves from three types of beans varieties (Phaseolus vulgaris L.), besides adjusting Peleg's model to the experimental 
values under several soaking temperatures.

\section{MATERIAL AND METHODS}

Bean seeds from the species Phaseolus vulgaris L. of pinto, black and red kidney bean varieties were used. The grains for realization of the experiment were acquired in local market in Palmas (TO - Brazil). Initially it was performed a selection of material to removal of impurities, excluding broken and abnormal grains and others.

\subsection{STORAGE CONDITIONS}

The initial moisture content from the samples was $0.17 ; 0.16$ and 0.14 (decimal dry basis) for the pinto, black and red kidney varieties respectively, being obtained through stove method, $105 \pm 1^{\circ} \mathrm{C}$, until constant mass (BRASIL, 2009).

\subsection{WATER ABSORPTION DETERMINATION DURING SOAKING}

In hydration process, samples with $20 \mathrm{~g}$ of seed were used. These samples were embedded in $80 \mathrm{~mL}$ of distilled water in beakers of $150 \mathrm{~mL}$, under temperatures of $20,30,40 \mathrm{e} 50^{\circ} \mathrm{C}$, using water bath with three repetitions for each temperature. For monitoring the water absorption, samples were weighed periodically, being removed from beakers and put over filter papers to dropping of superficial water during approximately two minutes. After weighing they were returned to immersion. Water absorption by grains continued until product had reached its equilibrium water content (RESENDE \& CORRÊA, 2007).

Water content for a given time after the beginning of the experiment was calculated based on mass increase of samples regarding to initial mass.

\subsection{MODELING THE OPERATION OF HYDRATION}

It was used, for modeling of bean hydration, Peleg's model (1988) according to following expression:

$$
U_{t}=U_{0}+\frac{t}{\left(C_{1}+C_{2} t\right)}
$$

Where:

$U_{t}=$ moisture content at time t, (decimal d.b.); $U_{0}=$ initial moisture content, (decimal d.b.); $t=$ soaking time, (h); $C_{1}=$ the Peleg rate constant (h decimal d.b. $\left.{ }^{-1}\right) ; C_{2}=$ the Peleg capacity constant (decimal d.b. $\left.{ }^{-1}\right)$

\subsection{STATISTICAL ANALYSIS}

To verify the degree of adjustment of Peleg's model and variation of constants in function of soaking temperature, it was performed a regression analysis using the Gauss Newton method, with the aid of the STATISTICA $7.0^{\circledR}$ software system (STATSOFT, 2004).

Degree of fit for each model considered significance of regression coefficient in t test at $1 \%$ probability level, the value of determination coefficient $\left(R^{2}\right)$, values of mean relative error $(P)$ and estimate standard error ( $S E$ ) were calculated by following equations:

$$
P=\frac{100}{n} \sum \frac{|Y-\hat{Y}|}{Y}
$$




$$
S E=\sqrt{\frac{\sum(Y-\hat{Y})^{2}}{G L R}}
$$

Where:

$Y=$ value experimentally observed; $\hat{Y}=$ value calculated by the model; $\mathrm{n}=$ soaking number of experimental observations; $G L R=$ degrees of freedom of model (number of observations minus number of model parameters).

\section{RESULTS AND DISCUSSION}

Values of determination coefficients, mean relative error and estimated standard error to the Peleg's model adjusted during bean grains hydration in temperatures of $20,30,40$ and $50{ }^{\circ} \mathrm{C}$, are presented in the Table 1.

\section{TABLE 1 - DETERMINATION COEFFICIENTS $\left(R^{2}\right)$, MEAN RELATIVE ERRORS $(P)$ AND ESTIMATE STANDARD ERROR (SE), TO PELEG'S MODEL ADJUSTED DURING HYDRATION OF THREE BEAN VARIETIES UNDER SEVERAL CONDITIONS OF TEMPERATURE}

\begin{tabular}{|c|c|c|c|c|c|c|}
\hline $\begin{array}{l}\text { Varieties } \\
\text { of beans }\end{array}$ & $\begin{array}{c}\text { Soaking } \\
\text { temperature } \\
\left({ }^{\circ} \mathrm{C}\right)\end{array}$ & \begin{tabular}{l}
\multicolumn{1}{c}{$C_{1}$} \\
(Peleg rate \\
constant)
\end{tabular} & $\begin{array}{c}C_{2} \\
\text { (Peleg } \\
\text { capacity } \\
\text { constant) }\end{array}$ & $R^{2}(\%)$ & SE (decimal) & $P(\%)$ \\
\hline \multirow{4}{*}{ Pinto beans } & 20 & $1.0162^{* *}$ & $1.1037^{* *}$ & 79.72 & 0.0318 & 2.78 \\
\hline & 30 & $0.8097^{\star \star}$ & $1.1100^{* *}$ & 90.41 & 0.0151 & 1.08 \\
\hline & 40 & $0.7706^{* *}$ & $1.0722^{* *}$ & 90.26 & 0.0073 & \multirow{2}{*}{$\begin{array}{l}0.54 \\
1.20\end{array}$} \\
\hline & 50 & $0.5242^{* *}$ & $1.1353^{\text {** }}$ & 91.00 & 0.0160 & \\
\hline \multirow{4}{*}{$\begin{array}{l}\text { Black } \\
\text { beans }\end{array}$} & 20 & $2.6989^{* *}$ & $0.9036^{* *}$ & 99.21 & 0.0289 & 2.28 \\
\hline & 30 & $1.0228^{* *}$ & $1.0395^{* *}$ & 96.39 & 0.0123 & 0.98 \\
\hline & 40 & $0.7087^{\star \star}$ & $0.9918^{* *}$ & 93.93 & 0.0154 & \multirow{2}{*}{$\begin{array}{l}0.97 \\
0.92\end{array}$} \\
\hline & 50 & $0.5733^{* *}$ & $1.0463^{* *}$ & 88.27 & 0.0132 & \\
\hline \multirow{4}{*}{$\begin{array}{l}\text { Red kidney } \\
\text { beans }\end{array}$} & 20 & $3.9177^{\star \star}$ & $0.5779^{* *}$ & 99.86 & 0.0585 & 8.61 \\
\hline & 30 & $1.2337^{\star \star}$ & $0.9571^{\text {** }}$ & 95.24 & 0.0172 & 1.36 \\
\hline & 40 & $0.7061^{\text {** }}$ & $0.9934^{* *}$ & 90.15 & 0,0036 & \multirow{2}{*}{$\begin{array}{l}0.25 \\
0.85\end{array}$} \\
\hline & 50 & $0.5405^{\star \star}$ & $1.0695^{\star \star}$ & 91.63 & 0.0122 & \\
\hline
\end{tabular}

** Significant at the $1 \%$ probability level by t test.

It was verified that for the four temperatures used in inhibition solution from three bean varieties, the Peleg's model has presented significance of its regression parameters to level of $1 \%$ of probability by $t$ test; high values of determination coefficient (upper to $79 \%$, in comparative scale from 0 to $100 \%$ ) and reduced values of standard error of estimate and of mean relative error (lower than $10 \%$ ) (Table 1). This, according to Mohapatra and Rao (2005), indicates a satisfactory adjustment of model to experimental data. 
Constants $C_{1}$ for this experiment decreased as temperature was raised describing a quadratic relationship, in function of hydration temperature in accordance with results presented in Table 2. Botelho et al. (2010) and Resende and Corrêa (2007) also observed that the constant $C_{1}$ decreases with temperature to a zone of 35 to $75{ }^{\circ} \mathrm{C}$ and 20 to $50{ }^{\circ} \mathrm{C}$, respectively. According to Turhan, Sayar \& Gunasekaran (2002), constant $C_{1}$ is related to rate of mass transference, being that, the smaller are the $C_{1}$ values, the higher will be the initial rates of water absorption.

It was still observed, in the Table 1 , that the constants $C_{1}$ and $C_{2}$ of Peleg's model varied in function of soaking temperature can be estimated, satisfactorily, by means of equations $4,5,6,7,8$ and 9 (Table 2).

TABLE 2 - DEPENDENCE OF THE CONSTANTS $C_{1}$ (PELEG RATE CONSTANT) AND $C_{2}$ (PELEG CAPACITY CONSTANT) OF PELEG'S MODEL BY THE HYDRATION TEMPERATURE ( $T$ )

\begin{tabular}{cccc}
\hline Varieties of beans & Equation & $\mathbf{R}^{2}(\%)$ & \\
\hline \multirow{2}{*}{ Pinto beans } & $C_{1}=1.2007-0.0082 T-0.0001 T^{2}$ & 94.26 & $(4)$ \\
& $C_{2}=1.2414-0.0094 T+0.0001 T^{2}$ & 47.81 & $(5)$ \\
\hline \multirow{2}{*}{ Black beans } & $C_{1}=7.5813-0.2884 T+0.0003 T^{2}$ & 98.43 & $(6)$ \\
& $C_{2}=0,4884+0.0176 T-0.0001 T^{2}$ & 86.09 & $(7)$ \\
\hline \multirow{2}{*}{ Red kidney beans } & $C_{1}=12.256-0.5473 T+0.0063 T^{2}$ & 97.83 & $(8)$ \\
& $C_{2}=-0.463+0.0682 T-0.0008 T^{2}$ & 94.94 & $(9)$ \\
\hline
\end{tabular}

Once the constants $C_{1}$ and $C_{2}$ can be expressed in function of temperature, moisture content of bean grains during soaking can be predicted by means of expressions described in the Table 3 .

\section{TABLE 3 - EQUATIONS TO ESTIMATE THE MOISTURE CONTENT OF THE BEAN GRAINS ACCORDING TO PELEG'S MODEL}

\begin{tabular}{ccc}
\hline $\begin{array}{c}\text { Varieties } \\
\text { of beans }\end{array}$ & Equation \\
\hline $\begin{array}{c}\text { Pinto } \\
\text { beans }\end{array}$ & $U_{1}=U_{0}+\frac{t}{\left(1.2007-0.0082 T-0.0001 T^{2}\right)+\left(1.2414-0.0094 T+0.0001 T^{2}\right) t}$ & (10) \\
\cline { 2 - 3 } $\begin{array}{c}\text { Black } \\
\text { beans }\end{array}$ & $U_{1}=U_{0}+\frac{t}{\left(7.256-0.2884 T+0.003 T^{2}\right)+\left(0.4884+0.0176 T-0.0001 T^{2}\right) t}$ & $(11)$ \\
\cline { 2 - 3 } $\begin{array}{c}\text { Red kidney } \\
\text { beans }\end{array}$ & $U_{1}=U_{0}+\frac{t}{\left(12.256-0.5473 T+0.0063 T^{2}\right)+\left(-0.463+0.0682 T-0.0008 T^{2}\right) t}$ & \\
\hline
\end{tabular}

In Figures 1, 2 and 3, are presented experimental and predicted moisture contents by Peleg's model during soaking of three varieties of bean in different temperatures. It was observed that the beginning of the hydration process, for three varieties, exhibited a high rate of water absorption, tending to decrease and stabilize with time, as moisture content of product approached of equilibrium, exhibiting a characteristic behavior of agricultural products submitted to hydration process, as stated by Botelho et al. (2010). 


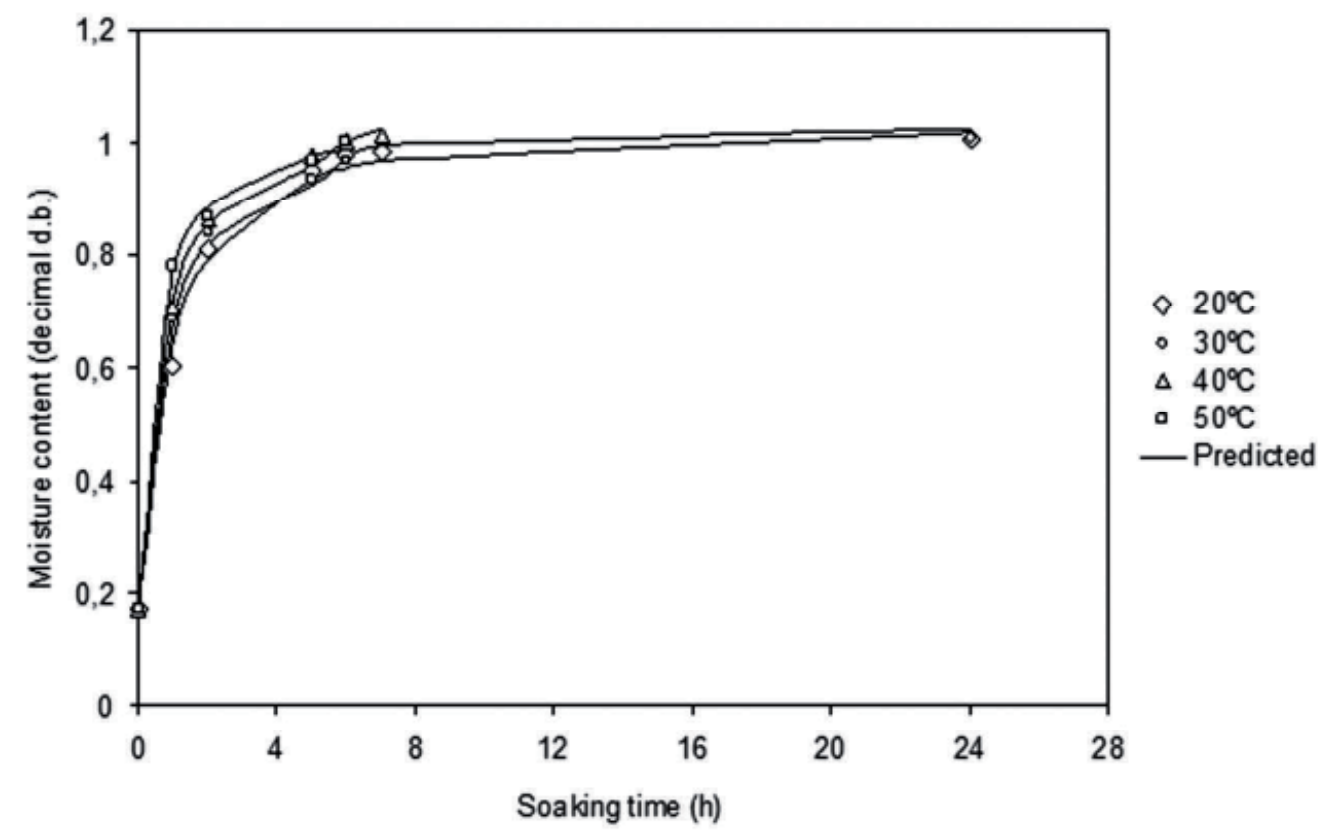

FIGURE 1 - EXPERIMENTAL AND PREDICTED MOISTURE CONTENTS BY PELEG'S MODEL DURING SOAKING OF BEAN GRAINS FROM PINTO VARIETY IN THE TEMPERATURES OF 20, 30, 40 AND $50^{\circ} \mathrm{C}$

According to Resende and Corrêa (2007), quick rise of water absorption in the initial phase of hydration is mainly due to natural capillarity existent in outer layers of the grains, near the hilum and diffusion process. Another factor on which high initial rates of water absorption could be attributed, as indicated by Botelho et al. (2010), occurs as consequence to matrix potential of several tissues of dried grains that is extremely reduced.

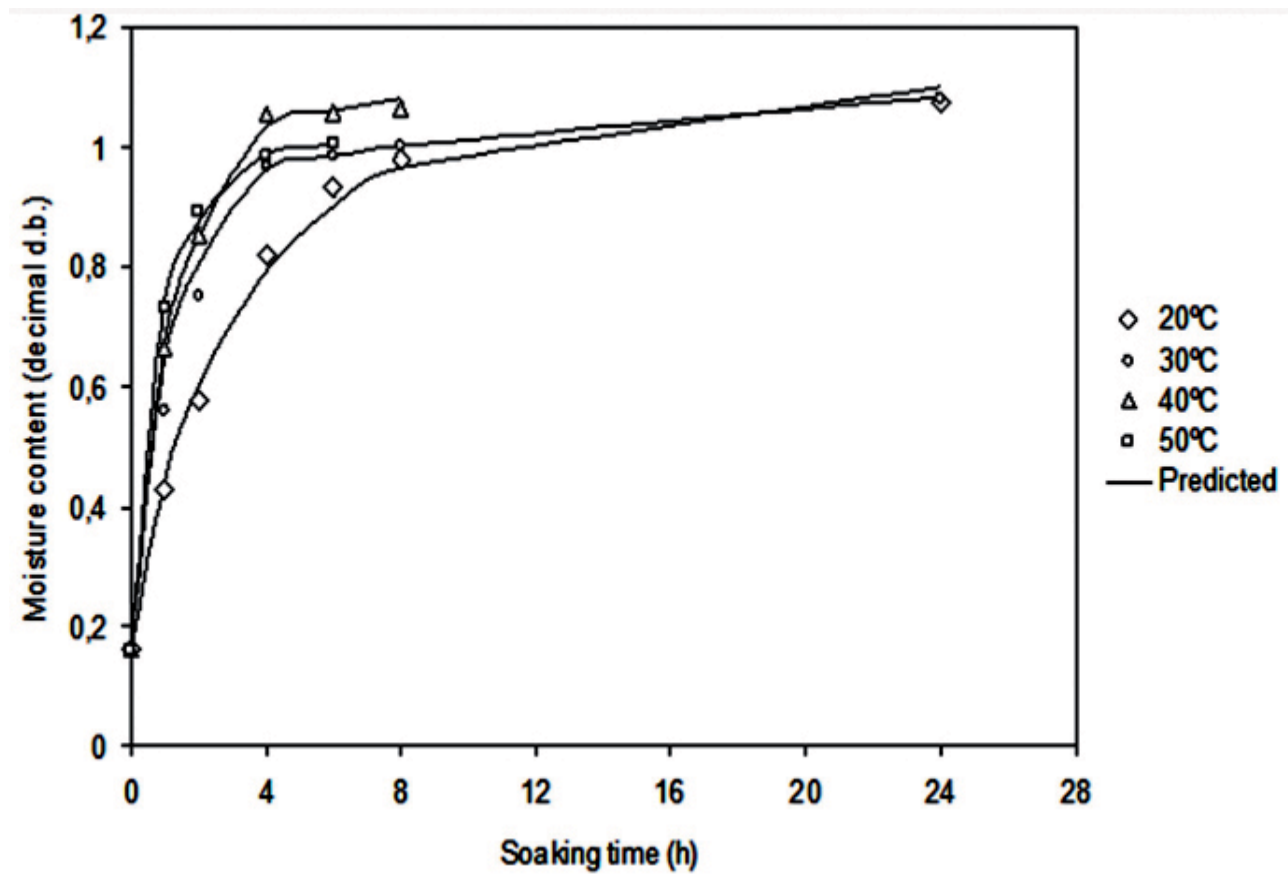

FIGURE 2 - EXPERIMENTAL AND PREDICTED MOISTURE CONTENTS BY PELEG'S MODEL DURING SOAKING OF BEAN GRAINS FROM BLACK VARIETY IN THE TEMPERATURES OF 20, 30, 40 AND $50^{\circ} \mathrm{C}$ 


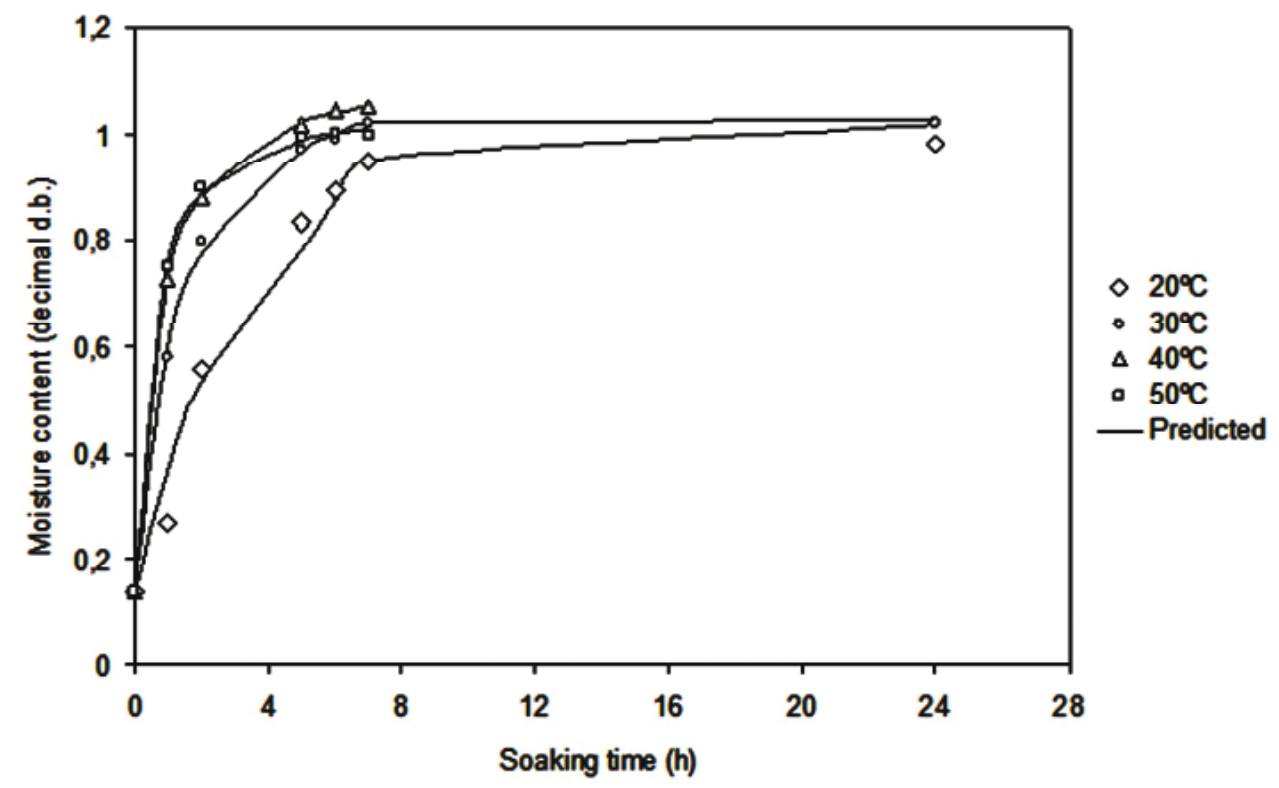

FIGURE 3 - EXPERIMENTAL AND PREDICTED MOISTURE CONTENTS BY PELEG'S MODEL DURING SOAKING OF BEAN GRAINS FROM RED KIDNEY

VARIETY IN THE TEMPERATURES OF 20, 30, 40 AND $50{ }^{\circ} \mathrm{C}$

According to Botelho (2009) to occur water movement in grain is necessary the existence of a driving force, in other words, a gradient of water concentration between surface and inner of the product. Thus, the higher is the gradient the higher will be the speed of water absorption.

In Figures 4, 5 and 6, it was presented graph of correspondence to values of moisture content, experimental and predicted by Peleg's model, with their constants ranging in function of temperature, during soaking of bean grains in temperature range between 20 to $50^{\circ} \mathrm{C}$. It was verified, by means of correspondence to experimental and predicted values as well as by magnitude of the $P$ and SE values, that Peleg's model represented in function of soaking temperature described the studied phenomenon accurately.

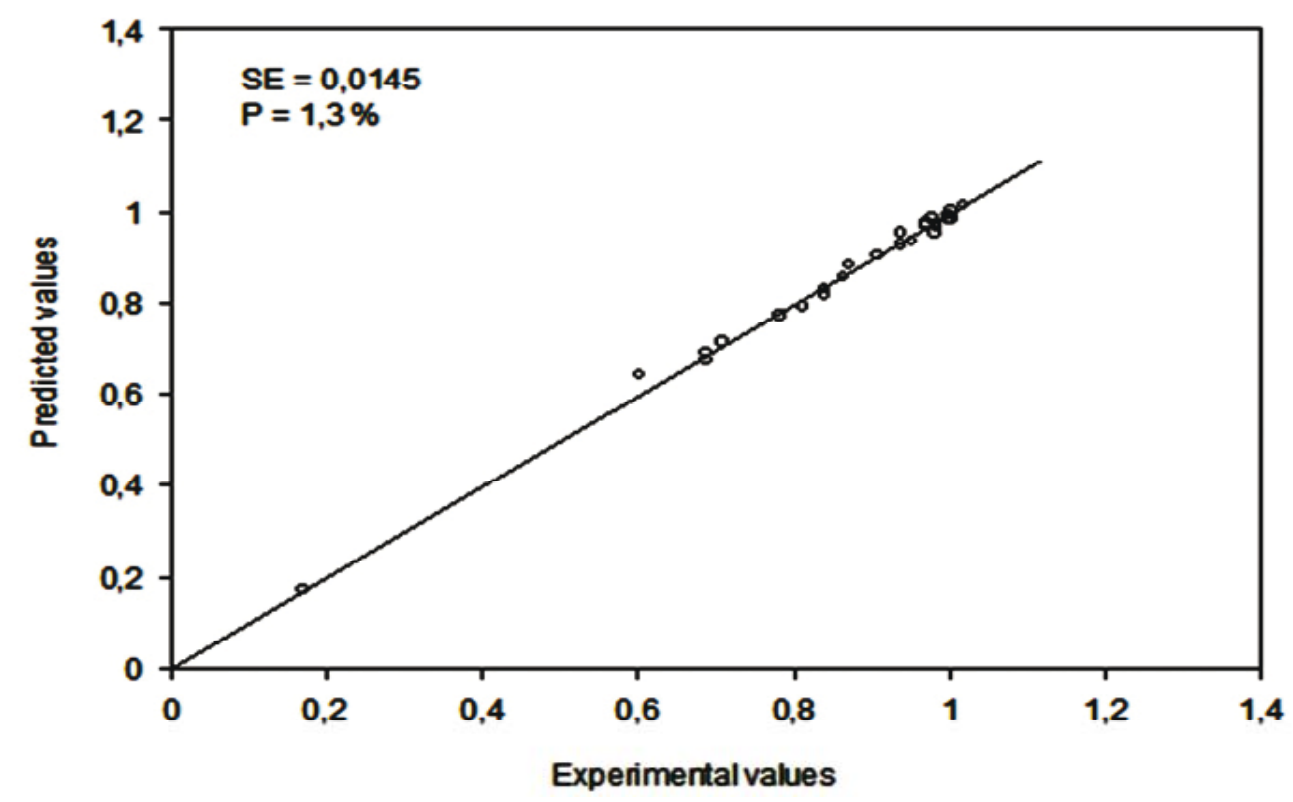

FIGURE 4 - CORRESPONDENCE BETWEEN EXPERIMENTAL AND PREDICTED VALUES BY PELEG'S MODEL WITH THEIR CONSTANTS RANGING IN FUNCTION OF TEMPERATURE, DURING SOAKING OF BEAN GRAINS FROM PINTO VARIETY IN THE TEMPERATURES OF $20,30,40$ AND $50^{\circ} \mathrm{C}$ 


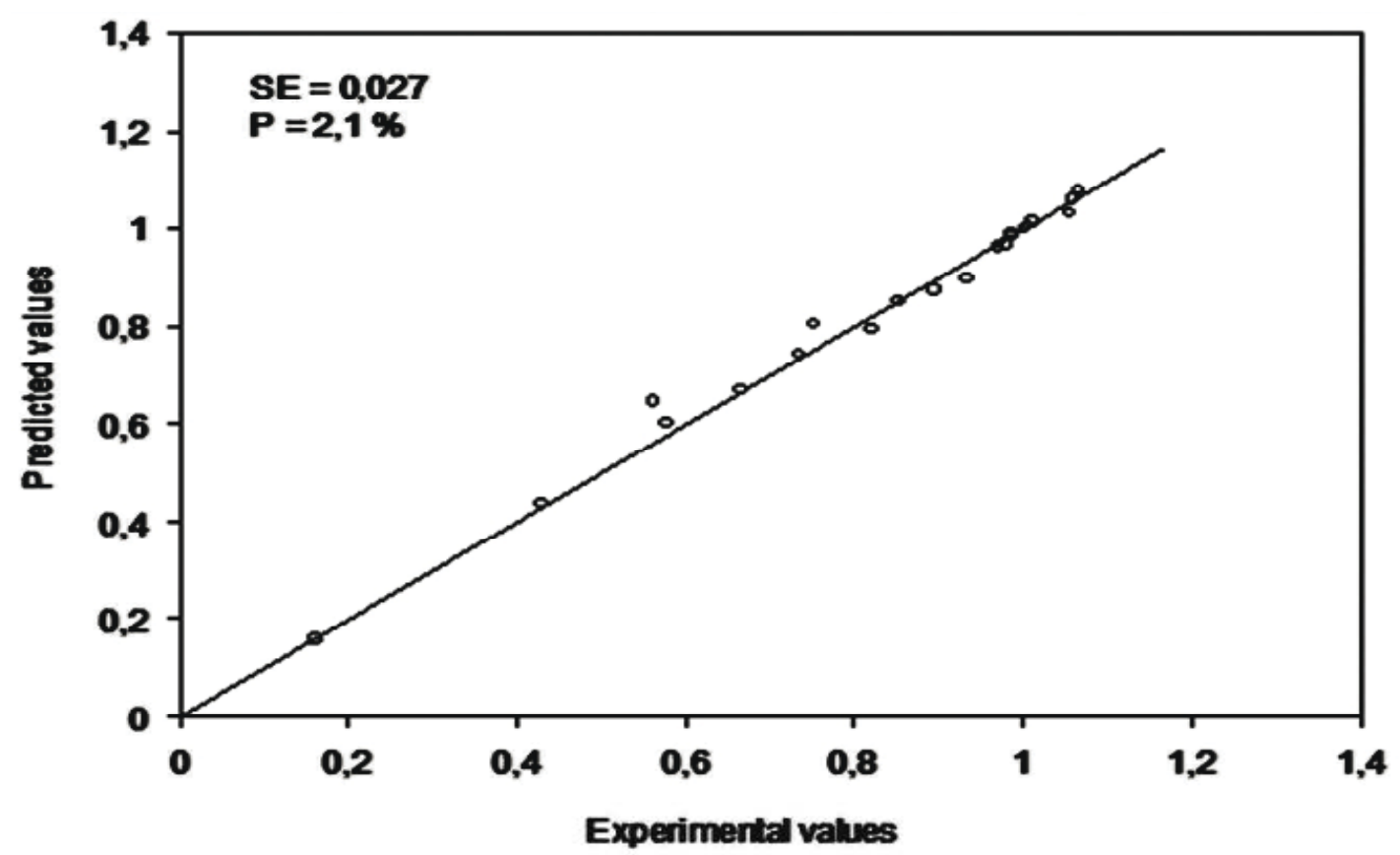

FIGURE 5 - CORRESPONDENCE BETWEEN EXPERIMENTAL AND PREDICTED VALUES BY PELEG'S MODEL WITH THEIR CONSTANTS RANGING IN FUNCTION OF TEMPERATURE, DURING SOAKING OF BEAN GRAINS FROM BLACK VARIETY IN THE TEMPERATURES OF $20,30,40$ AND $50^{\circ} \mathrm{C}$

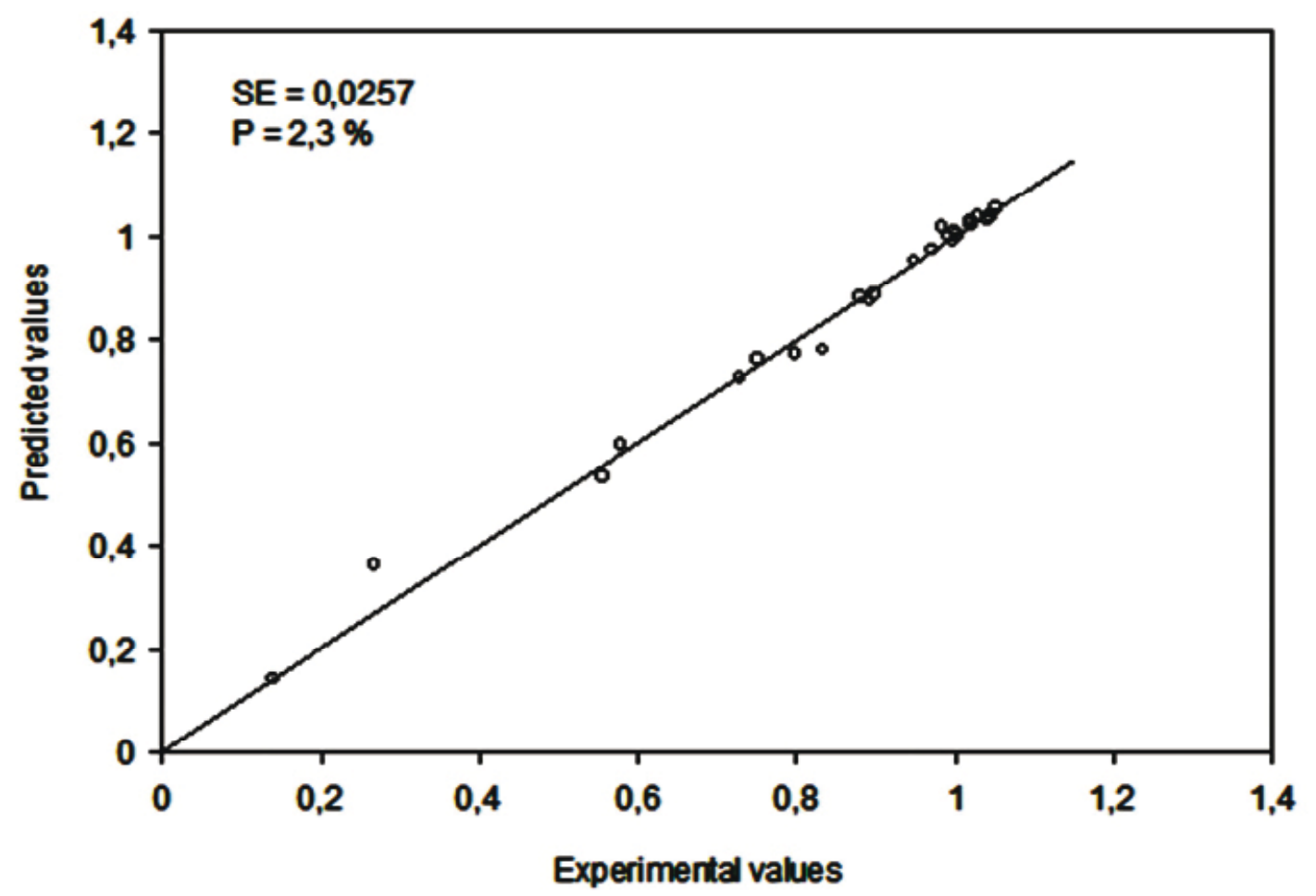

FIGURE 6 - CORRESPONDENCE BETWEEN EXPERIMENTAL AND PREDICTED VALUES BY PELEG'S MODEL WITH THEIR CONSTANTS RANGING IN FUNCTION OF TEMPERATURE, DURING SOAKING OF BEAN GRAINS FROM RED KIDNEY VARIETY IN THE TEMPERATURES OF 20, 30, 40 AND $50^{\circ} \mathrm{C}$ 


\section{CONCLUSION}

In the beginning of hydration process the three bean varieties, pinto, black and red kidney, exhibited a high rate of water absorption stabilizing over time, during soaking in temperatures of 20 , 30,40 and $50^{\circ} \mathrm{C}$.

Constant $C_{1}$ (Peleg rate constant) decreased quadratically with the raising of hydration temperature. Peleg's model fits well to hydration phenomenon of three varieties.

\section{RESUMO}

\section{ABSORÇÃo DE ÁGUA EM SEMENTES DE FEIJÃO (Phaseolus vulgaris L.) DURANTE O PROCESSAMENTO}

O objetivo deste trabalho foi estimar e avaliar as curvas de hidratação de três tipos de variedades de feijão (Phaseolus vulgaris), além de ajustar o modelo de Peleg aos valores experimentais na embebição dos grãos sob diferentes temperaturas. Foram utilizados grãos de feijão das variedades pinto, black e red kidney submetidos à embebição em água destilada nas temperaturas de $20,30,40$ e $50^{\circ} \mathrm{C}$. As constantes $C_{1}$ (taxa constante de Peleg) diminuiram significativamente com o aumento da temperatura $\left(20\right.$ a $\left.50^{\circ} \mathrm{C}\right)$, demonstrando que as taxas iniciais de absorção de água aumentaram conforme a temperatura. As três variedades de feijão (pinto, black, red kidney) exibiram alta taxa de absorção de água no início do processo de hidratação, sendo que o modelo de Peleg ajustou-se satisfatoriamente aos dados experimentais.

PALAVRAS-CHAVE: FEIJÃO; IMERSÃO; ABSORÇÃO DE ÁGUA; MODELO DE PELEG.

\section{REFERENCES}

1 BOTELHO, F.M. Absorção de água por grãos de milho com diferentes níveis de danificação mecânica. 2009. 81 p. MSc thesis, (Agricultural Engineering), Federal University of Viçosa, Viçosa, Minas Gerais, 2009.

2 BOTELHO, F.M.; CORRÊA, P.C.; GONELI, A.L.D.; MARTINS, M.A.; BAPTESTINI, F.M. Análise da hidratação do arroz na parboilização. Ciência e Tecnologia de Alimentos, v. 30, n. 3, p. 713-718, 2010.

3 BRASIL. Ministério da Agricultura, Pecuária e Abastecimento. Secretaria Nacional de Defesa Agropecuária. Regras para análises de sementes. Brasília, DF, 2009. p. 399.

4 CONAB.Campanhia Nacional de Abastecimento. Acompanhamento de safra brasileira: grãos, sétimo levantamento. Brasília, DF. Available on:<http://www.conab. gov.br/conabweb/download/safra/6graos_09.03.10.pdf >. Accessed at: March 30, 2011.

5 CHAVES, M.O. Oportunidades e desafios para a exportação de feijão no Brasil. Available on: < http://www.cnpaf. embrapa.br/noticias/2011pnoticia_079a.php>. Accessed at: 15 October 2011.

6 COSTA, M.R. Melhoramento de feijões preto e vermelho visando a resistência à antracnose, ferrugem e manchaangular, com auxílio de marcadores moleculares. 2007. 100 p. DSc thesis (Genetics and Breeding Graduate Program), Federal University of Viçosa, Viçosa, 2007.

7 COUTINHO, M.R. Modelagem, simulação e análise da hidratação de grãos de soja. 2006. 200 p. DSc thesis (Department of Chemical Engineering), Federal University of Maringá, Maringá, 2006.

8 EMBRAPA. Empresa Brasileira de Pesquisa Agropecuária. Cultivo do feijoeiro comum. Available on: http:// sistemasdeproducao. cnptia.embrapa.br>. Accessed at: October 15, 2011.

9 FIEP. Federação das Indústrias do Estado do Paraná. Feijão: (2006). Versão 1.0. Available on: <www.fiepr.org.br>. Accessed at: October 15, 2011.

10 MOHAPATRA, D.; RAO, P. S. A thin layer drying model of parboiled wheat. Journal of Food Engineering, v.66, n.4, p. 513-518, 2005

11 MASKAN, M. Effect of processing on hydration kinetics of three wheat products of the same variety. Journal of Food Engineering, v.52, n.4, p.337-341 2002.

12 OLIVEIRA, J.E.D. O feijão na alimentação/nutrição do brasileiro: ontem e amanhã. In: CONGRESSO NACIONAL DE PESQUISA DE FEIJÃO (CONAFE). Goiânia. Anais ... v.2. p.1246-1247. 2005. Available on: <http://www.cnpaf.embrapa. br/conafe/pdf/palestra13.pdf>. Accessed at: 30 March 2011. 
13 PELEG, M. An empirical model for the description of moisture sorption curves. Journal of Food Science, v.53, n.4, p. 1216-1217, 1988.

14 RESENDE, O.; CORRÊA, P.C. Modelagem matemática do processo de hidratação de sementes de feijão. Acta Scientiarum Agronomy, v.29, n.3, p.373-378, 2007.

15 Sociedade Nacional de Agricultura (SNA). O feijão nosso de cada dia. Revista A Lavoura, v.109, n.657, p.20-21, 2006.

16 STATSOFT INC. Statistica 7.0. Tulsa, OK, 2004.

17 TURHAN, M.; SAYAR, S.; GUNASEKARAN, S. Application of Peleg model to study water absorption in chickpea during soaking. Journal of Food Engineering, v. 53, n. 2, p. 153-159, 2002. 